\title{
Herbivore-induced plant volatiles emitted from avocado shoots infested by Oligonychus yothersi (Acari: Tetranychidae) increases the attraction of micro-coleopterans
}

\author{
Tommy Rioja ${ }^{1,2}$, Ricardo Ceballos ${ }^{3 *}$, and Loreto Holuigue ${ }^{4}$ \\ ${ }^{1}$ Pontificia Universidad Católica de Chile, Facultad de Agronomía e Ingeniería Forestal, Av. Vicuña Mackenna 4860, Santiago, Chile. \\ ${ }^{2}$ Universidad de Tarapacá, Facultad de Ciencias Agronómicas, Campus Azapa km 12 Arica, Chile. \\ ${ }^{3}$ Instituto de Investigaciones Agropecuarias, INIA Quilamapu, Av. Vicente Méndez 515, Chillán, Chile. \\ *Corresponding author (rceballos@inia.cl). \\ ${ }^{4}$ Pontificia Universidad Católica de Chile, Facultad de Ciencias Biológicas, Av. Libertador Bernardo O’Higgins 340, Santiago, Chile.
}

Received: 1 April 2018; Accepted: 20 June 2018; doi:10.4067/S0718-58392018000300447

\begin{abstract}
The avocado red mite, Oligonychus yothersi (McGregor) (Acari: Tetranychidae), is a polyphagous pest that causes damage to a wide range of plants. In Chile, is commonly found in avocado (Persea americana Mill.) orchards, and the plant damage is expressed as a reduction of photosynthetic activity in leaves, causing defoliation of trees under severe attack conditions. Oligota pygmaea (Solier) (Staphylinidae) and Parastethorus histrio (Chazeau) (Coccinellidae) microcoleopteran predators are found on 'Hass' avocado orchards, infested by $O$. yothersi. This study investigated the role of volatile compounds released by avocado in response to $O$. yothersi infestation in the tritrophic interaction avocado- $O$. yothersi-O. pygmaea-P. histrio. Plant volatiles were collected from live plants by headspace technique on Porapak Q traps and analyzed by gas chromatography coupled to mass spectrometry (GC-MS). In the chemical analysis, several chemical groups were identified including terpenes, aromatic compounds, and green leaf volatiles. Eight chemical compounds were detected only in the infested plants volatile profile, and differences were observed in the emission of 10 compounds between infested and uninfested plants $(\mathrm{P}<0.05)$. The behavioral responses of the insects to plant volatiles were evaluated in a choice-test using a Y-tube as olfactometer. Uninfested plant volatiles were significantly attractive to $O$. yothersi, while infested plants volatile extract repelled the mites. Two compounds, $R$-limonene and $\alpha$-pinene, elicit an attractant behavioral response from $O$. yothersi. Oligota pygmaea and P. histrio females registered a strong attraction to volatiles from infested plants, and the compounds $(Z)-\beta$-ocimene and methyl salicylate detected only in infested plant also were attractive to predators.
\end{abstract}

Key words: Avocado red mite, Coccinellidae, methyl salicylate, monoterpenes, olfactory responses, Persea americana, Staphylinidae.

\section{INTRODUCTION}

Biogenic volatile organic compounds (BVOCs) are emitted constitutively by plants (Loreto et al., 2014). Several phytophagous insects use these chemicals as cues to find their host plants (Cao et al., 2014). Mechanical wounding, fungal colonization (Encinas-Basurto et al., 2017), insect egg deposition and elicitors in oral secretions of insects and mites 
increase the emission of some BVOCs through cascades of reactions at genetic and physiological levels (Maffei, 2010), provoking the biosynthesis and production of herbivore-induced plant volatiles (HIPVs) after herbivory (Lucas-Barbosa et al., 2011). Toxic compounds synthesized such as terpenoids and phenolics act directly on herbivores as repellents and deterrents; while indirect induced defenses, through HIPVs, act attracting the natural enemies of the herbivores as carnivorous predators (Mithöfer and Boland, 2012). The HIPVs are mainly composed of terpenoids, green leaf volatiles (GLVs), jasmonates and aromatic compounds, which are synthesized by different biochemical pathways including the isoprenoid, lipoxygenase and shikimate/tryptophan pathway (Köllner et al., 2013). Insect infested plants increase their emissions of monoterpenes as limonene, $\beta$-ocimene or linalool, of sesquiterpenes as bergamotene, $\beta$-farnesene or $\beta$-caryophyllene, of GLVs as (Z)-3-hexen-1-ol, (Z)-3-hexenyl acetate or (E)-2-hexenal, and of esters as methyl salicylate or methyl jasmonate (Kappers et al., 2011; Suckling et al., 2012). Several studies have shown that infested plants emit higher amounts of HIPVs attracting natural enemies since predators and parasitoids exploit food resources through HIPVs (Kessler and Heil, 2011; Ponzio et al., 2013). Similarly, HIPVs are associated with prey availability and ideal habitat conditions for the development of natural enemies' offspring, increasing the foraging efficiency (de Rijk et al., 2013). Therefore, the HIPVs provoke tritrophic interactions: Plants-herbivorous-carnivorous (Sabelis et al., 2011). A number of studies have mainly evaluated the attractions of parasitoids (Li et al., 2014) and predators to HIPVs released by insectinfested plants (Oliveira and Pareja, 2014). Equally, some studies have investigated the behavioral responses of phytoseiid mites to the HIPVs emitted by mite-infested plants (Ferrero et al., 2014), using blends of synthetic HIPVs as GLVs + methyl salicylate as odor source in laboratory conditions (Shimoda, 2010; van Wijk et al., 2011). There are few reports on the olfactory responses of predatory insects attracted to tetranychid mites-infested plants. Oligota kashmirica benefica (Coleoptera: Staphylinidae) was attracted to lima bean (Phaseolus lunatus L.) plants infested by Tetranychus urticae Koch (Acari: Tetranychidae); also, T. urticae-infested kidney bean (Phaseolus vulgaris L.) plants were attractive to Stethorus gilvifrons (Mulsant) (Coleoptera: Coccinellidae) females (Gencer et al., 2009). Some studies have investigated synthetic HIPVs as methyl salicylate and GLVs in field-conditions, where the lures attracted parasitoids (Simpson et al., 2011) and some predators, including Stethorus punctum picipes (Casey) (Coleoptera: Coccinellidae), and Orius tristicolor (Hemiptera: Anthocoridae) in commercial crops (Woods et al., 2011; Uefune et al., 2012).

The predators belong to Stethorus, Parastethorus and Oligota genera are considered highly effective natural enemies of tetranychid mites (Biddinger et al., 2009; Perumalsamy et al., 2009a; Perumalsamy et al., 2009b). These are incorporated as biological control agents in Integrated Pest Management programs (IPM) since they prey all the stages of tetranychid mites (Hoy, 2011). Despite the effectiveness and promising outcomes of Parastethorus histrio and Oligota pygmaea, the interaction at the tri-trophic levels plant-tetranychids-predators is not yet completely understood.

In the Valparaiso Region of Chile, 'Hass' avocado orchards are adversely affected by one of the most important foliar pest, $O$. yothersi (Rioja et al., 2015) whose stylet-like cheliceae pierces and sucks cell contents, like chlorophyll, from tissue leaves, affecting the physiological parameters of plants (Hoy, 2011). The coleopterans O. pygmaea and P. histrio have been observed on $O$. yothersi-infested avocado plants, preying on all stages of $O$. yothersi (Biddinger et al., 2009). The natural colonization and establishment of $O$. pygmaea and $P$. histrio on $O$. yotersi-infested plants suggest that both predators are attracted by chemical cues from avocado mite-infested plants. We hypothesized that the plant volatiles released by avocado induced by $O$. yothersi attract natural enemies of this mite. The objective of this study was to determine the role of the volatile compounds released in response to mite infestation in the interaction of avocado- $O$. yothersi-O. pygmaea and P. histrio.

\section{MATERIALS AND METHODS}

\section{Plants and insects rearing technique}

Two-years-old avocado plants 'Hass' on rootstock 'Mexicola' growing in seven pots $(1 \mathrm{~L})$, filled with organic soil and peat, were used for all the experiments. The plants were fertilized with Ultrasol Multipropósito (18-18-18) (Soquimich, Santiago, Chile), irrigated weekly and kept in two groups, uninfested and infested, in separate greenhouses of white muslin $(3 \times 2.5 \times 4 \mathrm{~m})$ to avoid pest damage under semi-field conditions in La Cruz (32 $\left.49^{\prime} \mathrm{S} ; 71^{\circ} 17^{\prime} \mathrm{W}\right)$, Valparaíso Region, Chile. 
Oligonychus yothersi (McGregor) was reared on 'Hass' avocado leaf discs (diameter $=8.5 \mathrm{~cm}$ ) placed into a petri dish (diameter $=9 \mathrm{~cm}$, height $=1.5 \mathrm{~cm})$ with wet cotton, to avoid leaf dehydration. The leaf discs were incubated at $23 \pm 3^{\circ} \mathrm{C}$, 10-50\% RH and a 16:8 h photoperiod (Rioja et al., 2015). Oligota pygmaea (Solier) and Parastethorus histrio (Chazeau) were collected from avocado trees infested by $O$. yothersi in La Cruz, on March 2014. Then, the adults of each species were separately transferred to plastic containers (diameter $=11 \mathrm{~cm}$, height $=14 \mathrm{~cm})$ with a gypsum bottom $(5 \mathrm{~cm}$ in depth) and covered with muslin. Oligonychus yothersi-infested leaf discs, as described above, were supplied to the predators every $4 \mathrm{~d}$ and the gypsum was moistened weekly; subsequently, the adults of each species were transferred to petri dishes for a $24 \mathrm{~h}$ period to lay eggs. For the rearing of $O$. pygmaea, the eggs were observed until hatching and the molts were used to differentiate each larval stage. Afterwards, third instar larvae were transferred to plastic containers with a gypsum bottom, as described above, with irregular holes on its surface for pupating. Containers were covered with black cloth until the adults emerged. To conduct the rearing of $P$. histrio, third instar larvae were moved to new infested avocado leaf discs until pupating, and then transferred to plastic containers with a gypsum bottom and covered with muslin (Rioja et al., 2015).

\section{Plant infestation with mites and volatiles trapping procedure}

Six avocado plants in a greenhouse were infested with $250 \pm 10$ mites per leaf, a shoot $(15-30 \mathrm{~cm}$ tall) with 4 to 6 fully developed leaves was selected and then attached a leaf disk infested with $O$. yothersi. The mites were allowed to feed on the plant until the volatile collection, and to avoid their escape, Stickem (Seabright Laboratories, Emeryville, California, USA) was applied to the base of the shoots. The number of mites was corroborated with a 10X handheld magnifying glass.

Plant volatiles collection was carried out for $24 \mathrm{~h}\left(\right.$ at $\left.1 \mathrm{~L} \mathrm{~min}^{-1}\right)$ by enclosing the selected shoots in $1.5 \mathrm{~L}$ polyethylene terephthalate (PET) bottles cut vertically and sealed with teflon. Volatiles were absorbed on $100 \mathrm{mg}$ Porapak Q columns (80-100 mesh, Waters Associates, Milford, Massachusetts, USA), previously cleaned with $1 \mathrm{~mL}$ of redistilled diethyl ether (Chromatographic grade; Merck, Darmstadt, Germany), and conditioned at $150{ }^{\circ} \mathrm{C}$ for $2 \mathrm{~h}$ in a stream of $70 \mathrm{~mL} \mathrm{~N}$ $\min ^{-1}$ (Ceballos et al., 2015). The entrainment was performed by using a positive/negative pressure air system. The air was dried and purified by passage through activated charcoal (8-20 mesh; Sigma Aldrich, St. Louis, Missouri, USA) and drawn through bottles. Volatiles were eluted with $1 \mathrm{~mL}$ redistilled hexane (Chromatographic grade, Optima Scientific, Green Bay, Wisconsin, USA) and stored at $4{ }^{\circ} \mathrm{C}$ until their analysis (Ceballos et al., 2015).

\section{Volatiles identification and olfactometric bioassay}

Volatile compounds were analyzed using a gas chromatograph coupled to a mass spectrometer (GC-MS, QP2010 Ultra, Shimadzu, Japan) equipped with an RTx 5 capillary column $(30 \mathrm{~m} \times 0.25 \mathrm{~mm}$ internal diameter, $0.25 \mu \mathrm{m}$ film thickness, Restek Corporation, Bellefonte, Pennsylvania, USA). The GC oven was programmed to remain at $40{ }^{\circ} \mathrm{C}$ for 2 min and increase at $5{ }^{\circ} \mathrm{C} \mathrm{min}{ }^{-1}$ to $225{ }^{\circ} \mathrm{C}$. Helium was used as carrier gas at $1.0 \mathrm{~mL} \mathrm{~min}^{-1}$ and the interface temperature was programmed at $250{ }^{\circ} \mathrm{C}$. Mass spectrum acquisition was performed in the mass range from 35 to $500 \mathrm{~m} / \mathrm{z}$. The ionization was performed by electron impact at $70 \mathrm{eV}$ with an ion source at $200{ }^{\circ} \mathrm{C}$. The volatiles collected were identified by comparing their retention times and mass spectrums with the NIST05 database (National Institute of Standards and Technology, Gaithersburg, Maryland, USA) library and commercial standards, and quantified using the internal standard method.

The behavioral response of $O$. pygmaea, $P$. histrio and $O$. yothersi was evaluated by testing avocado volatiles and six synthetic compounds identified in the volatile extract at four different concentrations $\left(0.1,1,10\right.$, and $\left.100 \mu \mathrm{g} \mathrm{mL}^{-1}\right)$. Bioassays were carried out using a glass Y-tube olfactometer $\left(8 \mathrm{~cm}\right.$ arm length, $1 \mathrm{~cm}$ internal diameter and $60^{\circ}$ angle). The observation area was divided into zones, one arm of Y-tube was designated as stimulus, the opposite arm was designated as control zone, and the base of Y-tube as a decision zone. Individual females, of each species, were released one at a time within the first centimeter of the base tube of the olfactometer, permeated by charcoal filtered air $\left(800 \mathrm{~mL}^{-1}\right)$ coming from each arm and drawn out through the base. Olfactometric bioassays were carried out between 11:00 and 17:00 $\mathrm{h}$ at $25 \pm 2{ }^{\circ} \mathrm{C}$ and $60-70 \mathrm{RH}$. The chemical stimuli (odors of plant extracts, synthetics compounds or hexane as control) were applied to a paper strip $(7 \mathrm{~cm} \times 5 \mathrm{~mm}$, Whatman $\mathrm{nr} 1$ filter paper) and placed into a glass tube $(10 \mathrm{~cm}$ high and $1 \mathrm{~cm}$ of outer diameter) connected to each olfactometer arm. The spent time in each zone of the olfactometer was recorded during 10 min with the olfactometer being rotated $\left(90^{\circ}\right.$ clockwise) in every experiment to minimize directional bias. Prior to each 
experiment, the test specimen was allowed to acclimatize for $5 \mathrm{~min}$ inside the olfactometer. The insects were tested only once, and 30 replicates were performed for each extract and species using a different clean-olfactometer.

\section{Statistical analysis}

Data from plant volatile emissions were submitted to statistical analysis trough Student's $t$-test $(\mathrm{P}<0.05)$, prior to the analysis data were transformed by $\operatorname{Ln}(x+1)$ to accomplish the normality requirements of the analysis. The time spent by insects in different zones of the olfactometer was submitted to ANOVA and groups were separated using Tukey's test $(\mathrm{P}<0.05)$. Olfactometric responses to infested and uninfested plant volatiles were analyzed trough Student's $t$-test $(\mathrm{P}<0.05)$. An olfactometric-preference index $(\mathrm{OPI})$, where $\mathrm{OPI}=2 \mathrm{~T} /(\mathrm{T}+\mathrm{C})$ (Ceballos et al., 2015), was calculated to reflect the effect of the synthetics compounds on the behavior of the insects. The OPI values ranged from 0 to 2 , with $\mathrm{OPI}=1$ indicating no olfactometric preference for the control or treatment odor source, OPI $>1$ indicating preference for treatment odor source, and OPI $<1$ indicating preference for control odor source. Values of OPI were analyzed with non-parametric one-way analyses based on ranks trough Kruskal-Wallis's H-test followed by Mann-Whitney's U-test $(\mathrm{P} \leq 0.05)$ and corrected by Bonferroni procedure for multiple comparisons.

\section{RESULTS AND DISCUSSION}

\section{Identification of plant volatile compounds}

The GC-MS analysis of volatile compounds showed both qualitative and quantitative differences in the emissions of mite infested and uninfested avocado plants. Large and significantly different quantities of $(E)$ - $\beta$-ocimene were found in infested $\left(282 \mu \mathrm{g} \mathrm{mL}^{-1}\right)$ and uninfested $\left(3.75 \mu \mathrm{g} \mathrm{mL}^{-1}\right)$ plants (Figure 1). Ten compounds were identified in both uninfested and infested plant volatiles, but higher emissions were detected in infested plants except 6-ethyl-2-methyloctane; 3,3-dymethylhexane and $R$-limonene whose emissions were significantly higher in uninfested plants, $3.41,2.11$, and $2.15 \mu \mathrm{g} \mathrm{mL}^{-1}$ respectively. Eight compounds were exclusively detected in mite infested plants $(Z)$-3-hexen-1-ol $\left(0.35 \mu \mathrm{g} \mathrm{mL}^{-1}\right)$, 3-hexen-1-ol-benzoate (3.45 $\left.\mu \mathrm{g} \mathrm{mL}^{-1}\right), \beta$-myrcene $\left(0.65 \mu \mathrm{g} \mathrm{mL}^{-1}\right),(Z)$ - $\beta$-ocimene $\left(8.11 \mu \mathrm{g} \mathrm{mL}^{-1}\right), \beta$-linalool $\left(22.6 \mu \mathrm{g} \mathrm{mL}^{-1}\right), \alpha$-farnesene $(37.8 \mu \mathrm{g}$ $\left.\mathrm{mL}^{-1}\right)$, farnesyl cyanide $\left(18.9 \mu \mathrm{g} \mathrm{mL}^{-1}\right)$ and methyl salicylate $\left(94.1 \mu \mathrm{g} \mathrm{mL}^{-1}\right)$ (Figure 1). The HIPVs identified were induced in response to $O$. yothersi-feeding in avocado plants (Rioja et al., 2016); those chemical compounds belong from different pathways such as GLVs, monoterpenes, sesquiterpenes and aromatic compounds, mainly. The highest emission rates were exhibited by (E)- $\beta$-ocimene, $\beta$-linalool, methyl salicylate, and $\alpha$-farnesene. These compounds have been found in other

Figure 1. Volatile compounds released from infested and uninfested avocado plants. 1) 3-Hexanone, 2) 2-hexanone, 3) 3-hexanol, 4) (Z)-3-hexen-1-ol, 5) 3-hexen-1-ol-benzoate, 6) 2,3,4-trimethylhexane, 7) 6-ethyl-2-methyloctane, 8) 3,3-dimethylhexane, 9) $\alpha$-pinene, 10) $\beta$-pinene, 11) $\beta$-myrcene, 12) $R$-limonene, 13) $(Z)$ - $\beta$-ocimene, 14) $(E)$ - $\beta$-ocimene, 15) $\beta$-linalool, 16) $\alpha$-farnesene, 17) farnesyl cyanide, 18) methyl salicylate.

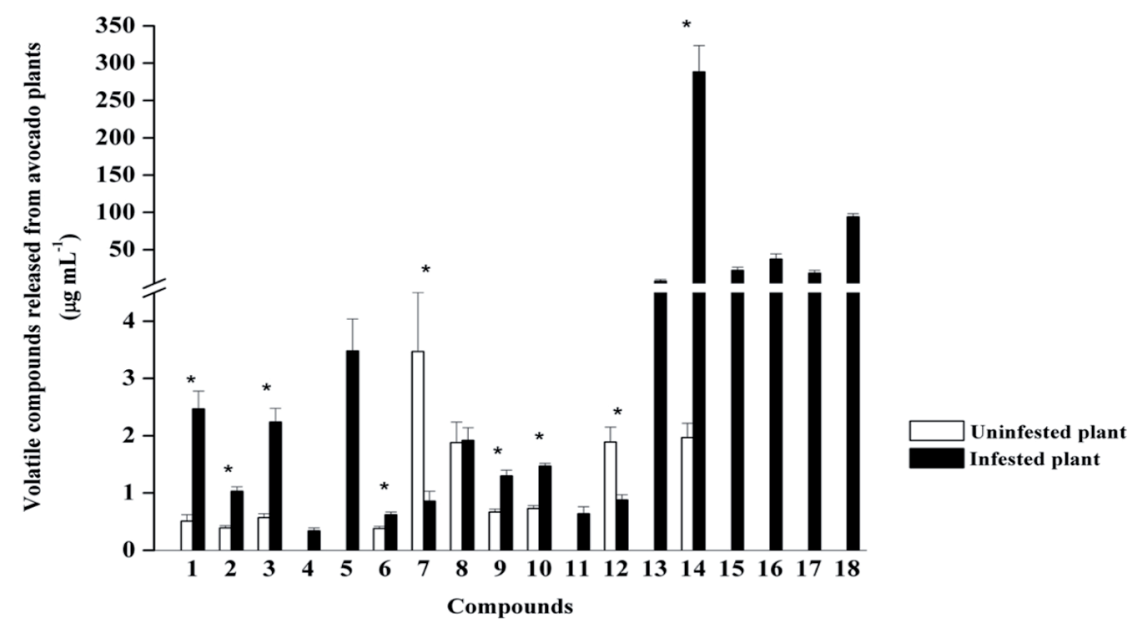

Data represent mean \pm standard errors $(n=6)$.

*Significant differences in the amounts of volatiles released by avocado plants (Student's t-test, $\mathrm{P}<0.05$ ). 
mite-infested plants, encompassing Lotus japonicus L., tea (Camellia sinensis L.), cucumber and lima bean plants (Shimoda, 2010; Kappers et al., 2011; Ozawa et al., 2012). Therefore, we found that volatile chemicals released by avocado plants in response to feeding of $O$. yothersi were both qualitatively and quantitatively different from uninfested avocado plants.

\section{Olfactory response toward plant volatiles}

Olfactometric bioassay showed that both $P$. histrio and $O$. pygmaea were attracted to infested plant volatiles. Females of $P$. histrio showed significant (U-test: $\mathrm{Z}=-6.6471 ; \mathrm{P}=0.0001$ ) attraction to mite infested plant volatiles spending $66.7 \%$ of the bioassay time in the plant stimulus zone, and were unable to discriminate $(\mathrm{Z}=-0.9983, \mathrm{P}=0.3146)$ the uninfested plants in the olfactometer (Figure 2). Likewise, O. pygmaea females showed no preference $(\mathrm{Z}=0.0961$, $\mathrm{P}=0.9176$ ) for any volatiles from uninfested plants, control or decision zone in the olfactometric bioassay. Oligota pygmaea demonstrated the highest $(71.7 \%)$ and significant $(\mathrm{Z}=-6.6365, \mathrm{P}=0.0001)$ discriminating behavior for infested plant volatiles (Figure 3). HIPVs are emitted in response to herbivory and attract natural enemies of herbivores, thereby

Figure 2. Olfactory responses of Parastethorus histrio in Y-tube olfactometer experiments to avocado plant volatiles. Average time spent $( \pm \mathrm{SD})$ by $P$. histrio in the olfactometer $(\mathrm{n}=30)$.

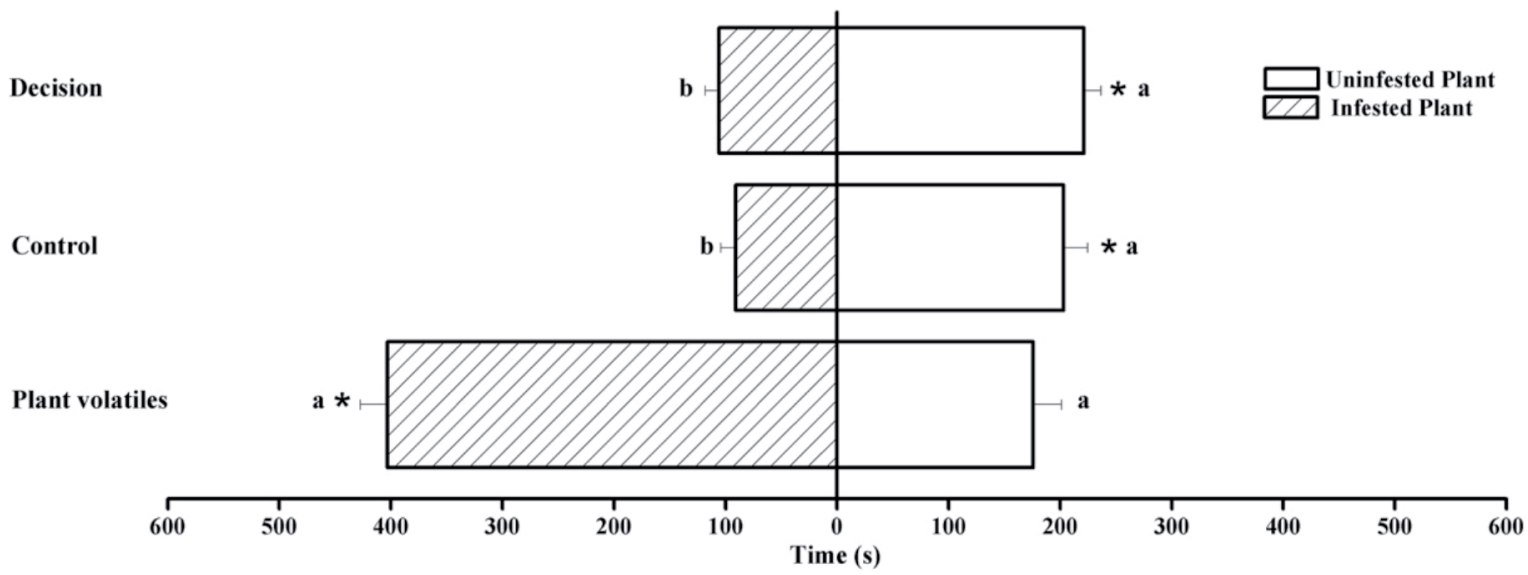

*Significant differences between infested and uninfested plant volatiles (Mann-Whitney's U-Test, $\mathrm{P}<0.05$ ). Bars sharing a letter, for each treatment, are non-significantly different based on Tukey's test $\mathrm{P}<0.05$ ).

Figure 3. Olfactory responses of Oligota pygmaea in Y-tube olfactometer experiments to avocado plant volatiles. Average time spent $( \pm \mathrm{SD})$ by $O$. pygmaea in the olfactometer $(n=30)$.

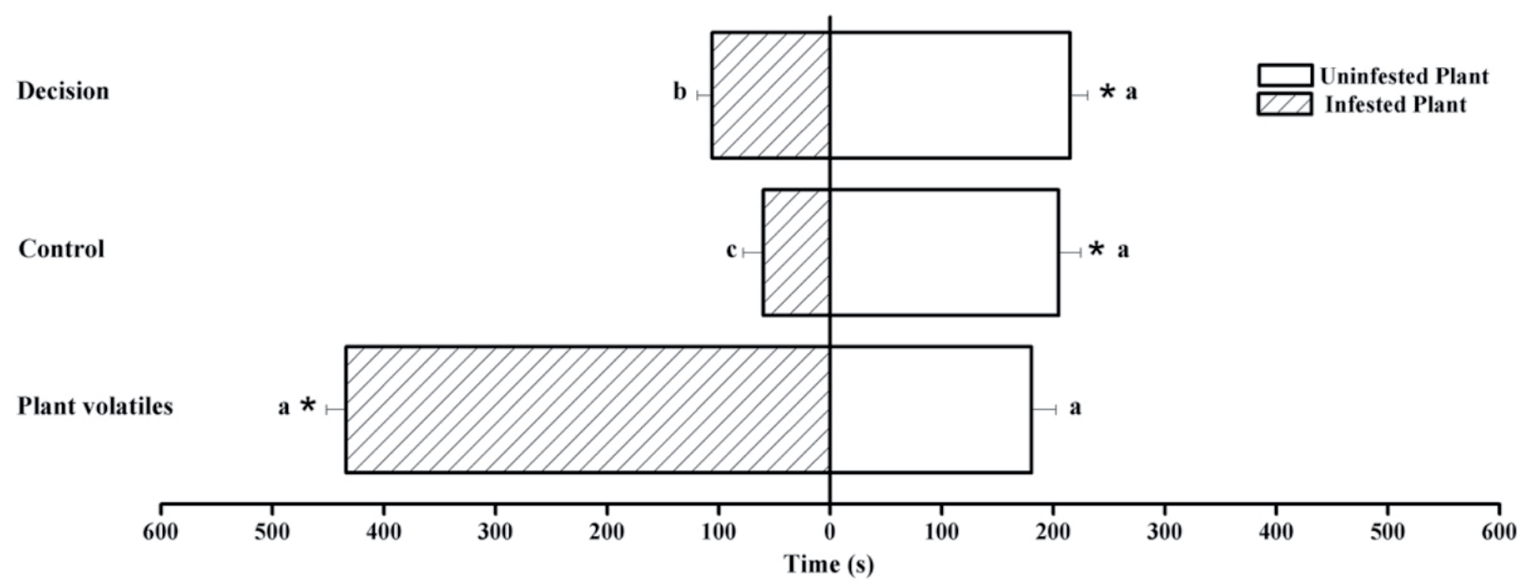

*Significant differences between infested and uninfested plant volatiles (Mann-Whitney's U-Test, $\mathrm{P}<0.05$ ). Bars sharing a letter, for each treatment, are non-significantly different based on Tukey's test $\mathrm{P}<0.05$ ). 
inducing an important indirect defense against herbivores (Choh and Takabayashi, 2010). Few studies have evaluated olfactory responses to HIPVs of predators from the genera Stethorus and Oligota. Gencer et al. (2009) found that ladybird beetle Stethorus gilvifrons (Mulsant) (Coleoptera: Coccinellidae) was significantly attracted to HIPVs released from sweet pepper (Capsicum annuum L.), kidney bean (Phaseolus vulgaris L.) and apple (Pyrus malus L.) plants infested by T. urticae and/or Panonychus ulmi (Koch) (Acari: Tetranychidae). The predator Wollastoniella rotunda (Yasunaga and Miyamoto) (Hemiptera: Anthocoridae) was attracted to eggplants (Solanum melongena L.) infested by Tetranychus kanzawai (Kishida) (Acari: Tetranychidae) (Uefune et al., 2010), indicating that mite-feeding provoke the production and emission of secondary metabolites as an indirect defense. To our knowledge, olfactory responses of the species Parastethorus genus to avocado plant infested by $O$. yothersi, had not been carried out previously.

On the other hand, $O$. yothersi females were substantially attracted to volatiles released by uninfested plants $(\mathrm{Z}=$ $-5.8300, P=0.0001)$, and repelled by infested plant volatiles $(Z=4.0413, P=0.0001)$ (Figure 4). On that subject, Cao et al. (2014) found that the Western Flower Thrips (WFT) Frankliniella occidentalis (Pergande) (Thysanoptera: Thripidae) females were strongly attracted to the odors from cabbage (Brassica oleracea), lettuce (Lactuca sativa), cucumber (Cucumis sativus) and eggplant (S. melongena) uninfested plants. Thus, our results indicated that uninfested volatile plants are attractive and used as chemical cues in host-finding behavior by mites.

\section{Olfactory response toward synthetic compounds}

In the olfactometer $P$. histrio showed a dose-dependent response to $\alpha$-farnesene, significantly $(\mathrm{H}=13.0772, \mathrm{P}=0.0045)$ attracted at $0.1 \mu \mathrm{g} \mathrm{mL} \mathrm{m}^{-1}$ and noticeably repelled at $100 \mu \mathrm{g} \mathrm{mL}^{-1}$. Similarly, $R$-limonene elicited a dose-dependent response, at $0.1 \mu \mathrm{g} \mathrm{mL}-1$ P. histrio was repelled and showed a strong attraction when the dose increased to $100 \mu \mathrm{g} \mathrm{mL}$ $(\mathrm{H}=35.1188, \mathrm{P}=0.0001)$. Methyl salicylate and $\alpha$-pinene induced a significant attraction of $P$. histrio at low doses, and was attracted to high doses, 10 and $100 \mu \mathrm{g} \mathrm{mL} \mathrm{L}^{-1} \beta$-ocimene. Parastethorus histrio in the olfactometric bioassay showed an erratic response to linalool, attraction at $0.1 \mu \mathrm{g} \mathrm{mL}^{-1}$, repellence at $1 \mu \mathrm{g} \mathrm{mL}^{-1}$, no preference at $10 \mu \mathrm{g} \mathrm{mL}-1$ and attraction at $100 \mu \mathrm{g} \mathrm{mL}^{-1}$ (Figure 5). $R$-limonene, $\alpha$-pinene, $\beta$-ocimene and $\alpha$-farnesene elicited attraction of $O$. pygmaea in all the tested concentrations. Oligota pygmaea responses to methyl salicylate were dose dependent, markedly attracted at $1 \mu \mathrm{g} \mathrm{mL}-1$, attracted at $10 \mu \mathrm{g} \mathrm{mL}^{-1}$, moderately attracted at $100 \mu \mathrm{g} \mathrm{mL} \mathrm{L}^{-1}$ and substantially repelled at 1000 $\mu \mathrm{g} \mathrm{mL} \mathrm{m}^{-1}$. The response of $O$. pygmaea, as well as in $P$. histrio, was erratic to linalool, displaying slightly attraction at 0.1 $\mu \mathrm{g} \mathrm{mL}-1$, repellence at $1 \mu \mathrm{g} \mathrm{mL}^{-1}$, attraction at $10 \mu \mathrm{g} \mathrm{mL}^{-1}$ and repellence at $100 \mu \mathrm{g} \mathrm{mL}^{-1}$ (Figure 6). Oligota pygmaea and $P$. histrio were attracted to $R$-limonene and $\beta$-ocimene. Alhmedi et al. (2010) found that the harlequin ladybird Harmonia axyridis Pallas (Coleoptera: Coccinellidae) showed a strong attraction to limonene, which is present in blends

Figure 4. Olfactory responses of Oligonychus yothersi in Y-tube olfactometer experiments to avocado plant volatiles. Average time spent $( \pm \mathrm{SD})$ by $O$. yothersi in the olfactometer $(n=30)$.

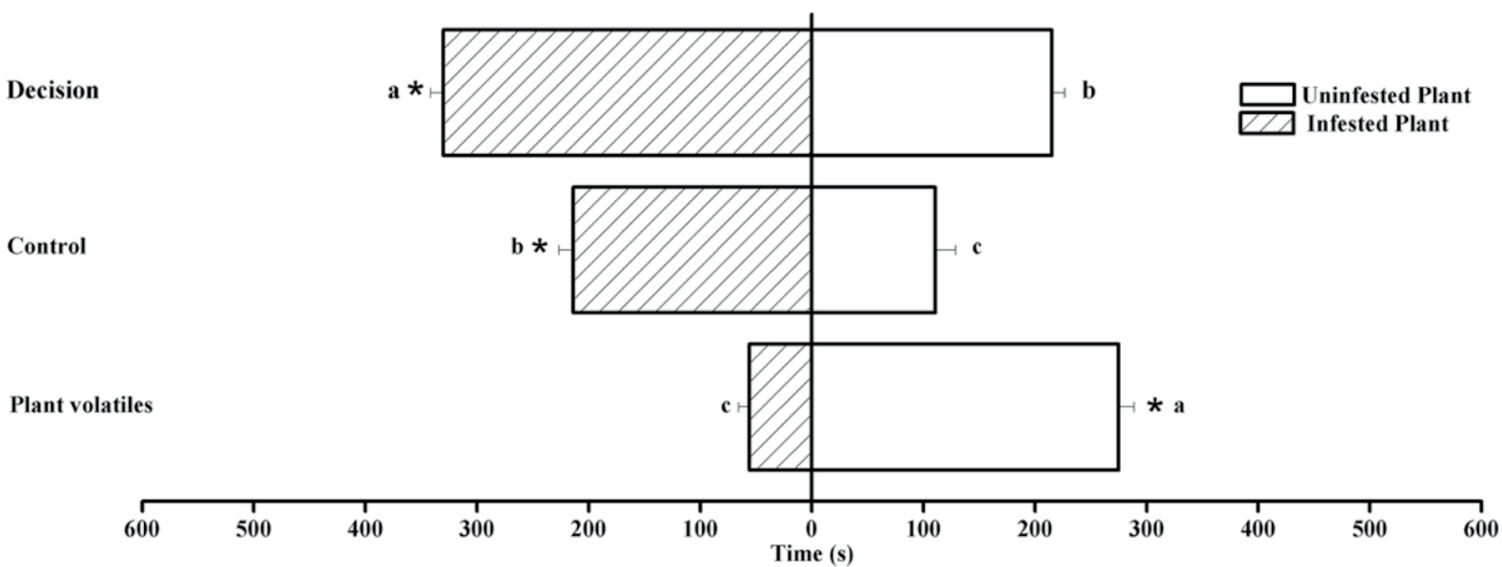

*Significant differences between infested and uninfested plant volatiles (Mann-Whitney's U-Test, P < 0.05). Bars sharing a letter, for each treatment, are non-significantly different based on Tukey's test $\mathrm{P}<0.05)$. 
Figure 5. Olfactory preference index (OPI) values of Parastethorus histrio to synthetic $\alpha$-pinene, $R$-limonene, farnesene (racemic mixture), linalool $\left(0.1,1,10\right.$, and $\left.100 \mu \mathrm{gL}^{-1}\right)$, ocimene (racemic mixture) and methyl salicylate $(1,10,100$ and $\left.1000 \mu \mathrm{gLL}^{-1}\right)$.
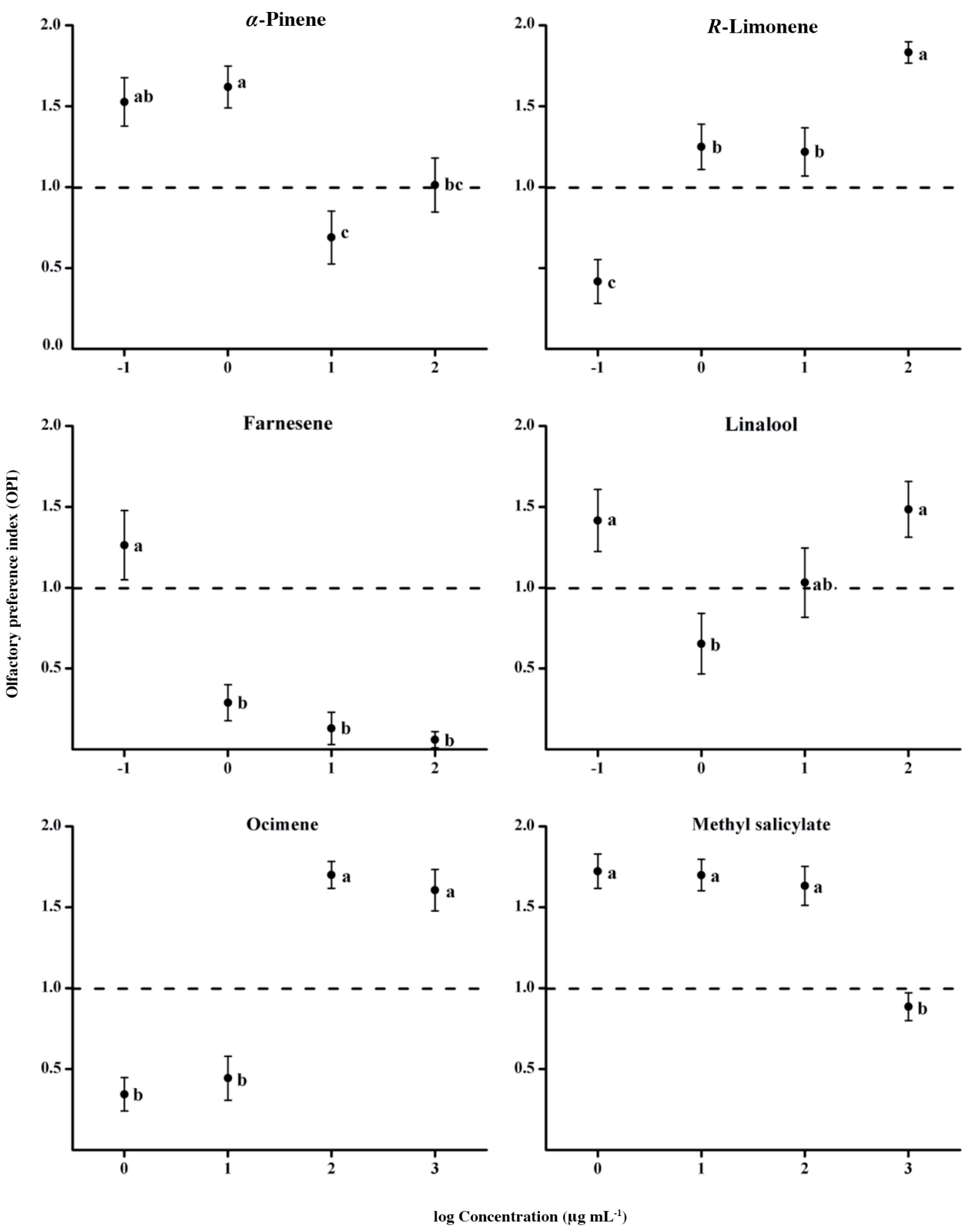

OPI values sharing a letter are non-significantly different based on Kruskal-Wallis test $(\mathrm{P}<0.05)$ followed by Mann-Whitney's $\mathrm{U}$-Test $(\mathrm{P}<0.05)$ weighted by the Bonferroni correction. 
Figure 6. Olfactory preference index (OPI) values of Oligota pygmaea to synthetic $\alpha$-pinene, $R$-limonene, farnesene (racemic mixture), linalool $(0.1,1,10$, and $100 \mu \mathrm{g} \mathrm{mL}-1)$, ocimene (racemic mixture) and methyl salicylate $(1,10,100$, and $1000 \mu \mathrm{g} \mathrm{mL}-1)$.
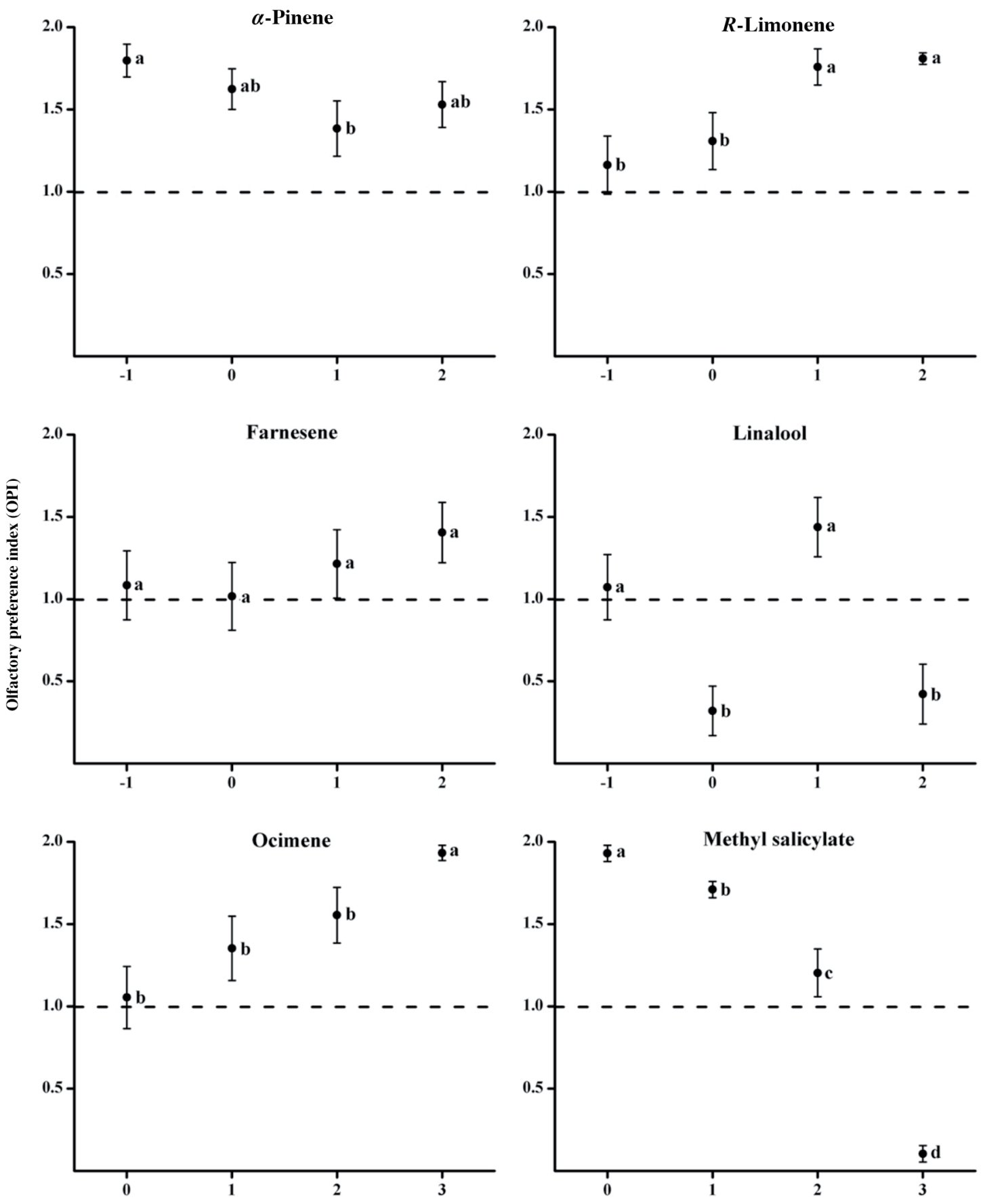

$\log$ Concentration $\left(\mu \mathrm{g} \mathbf{m L}^{-1}\right)$

OPI values sharing a letter are non-significantly different based on Kruskal-Wallis test $(\mathrm{P}<0.05)$ followed by MannWhitney's U-Test $(\mathrm{P}<0.05)$ weighted by the Bonferroni correction. 
from aphid-infested plants. This suggests that the coccinellids use limonene and ocimene as chemical cues to find their prey (Raghava et al., 2010; Ozawa et al., 2012; Suckling et al., 2012). Methyl salicylate attracts natural enemies of mites and aphids such as Orius tristicolor (White), Orius similis (Zheng) (Hemiptera: Anthocoridae), Chrysopa oculata (Say), Chrysopa nigricornis (Burmeister), Chrysoperla plorabunda (Fitch) (Neuroptera: Chrysopidae), Stethorus punctum picipes (Casey), Coccinella septempunctata (Linnaeus) (Coleoptera: Coccinellidae). Similarly, Methyl salicylate was attractive to Syrphidae and parasitoids in commercial crops, including hop (Humulus lupulus L.), grape (Vitis vinifera L.), apple (Malus domestica L.), strawberry (Fragaria ×ananassa), cranberry (Vaccinium macrocarpon), cotton (Gossypium hirsutum L.) and soybean (Glycine max) (Lee, 2010; Woods et al., 2011). Laboratory trials have demonstrated that the predatory mites $N$. californicus and Typhlodromus pyri are attracted to methyl salicylate at low concentrations (Shimoda, 2010; Gadino et al., 2012). This attraction of predatory mites could be explained by the learning process acquired in nonhost plants and non-prey rearing (Ishii and Shimada, 2012).

Oligonychus yothersi was repelled in all the doses by the tested compounds -methyl salicylate, $\alpha$-farnesene, $\beta$-ocimene, linalool, $\alpha$-pinene and $R$-limonene, except for 1 and $10 \mu \mathrm{gL}^{-1}$ of $\alpha$-pinene and $R$-limonene that elicited attraction (Figure 7), corroborating that $O$. yothersi females are attracted to volatiles released from uninfested plants, since both chemical compounds and its low dose were identified from blends of BVOCs emitted constitutively by avocado plants.

These findings suggest that avocado plants from Hass cultivar release HIPVs as indirect defense mechanism, attracting acarophagous insects. Our results could be useful to develop controlled-release dispensers with $R$-limonene, $\beta$-ocimene and methyl salicylate to recruit natural enemies and repel mites in avocado orchards.

\section{CONCLUSIONS}

Our finding indicates that 'Hass' avocado plants attacked by the red avocado mite Oligonychus yothersi release blends of herbivore-induced plant volatiles (HIPVs) as indirect defenses attracting both acarophagous insects Parastethorus histrio and Oligota pygmaea, indicating that these chemical cues are used for both micro coleopterans to find $O$. yothersi, also called tri-trophic interactions.

In relation to synthetic compounds offered, both $P$. histrio and $O$. pygmaea females distinguish between different concentrations of a same compound, being attracted to high concentrations of $R$-limonene and $\beta$-ocimene. In addition, both micro coleopterans were attracted to low concentrations of methyl salicylate, corroborating that those HIPVs are used to find specific preys. On the other hand, $O$. yothersi females were attracted to low concentrations of both monoterpenes $R$-limonene and $\alpha$-pinene suggesting that the avocado red mite use those monoterpenes as chemical cues to find host plant.

The monoterpenes $\alpha$-pinene, $R$-limonene and $\beta$-ocimene, and the aromatic methyl salicylate are key compounds and can be used to make controlled-release dispensers at specific concentrations, to recruit natural enemies of mites in conservation programs of biological control on avocado orchards, incorporating new technologies as alternative to broadspectrum pesticides.

\section{ACKNOWLEDGEMENTS}

Financial support of this study was supplied by CONICYT (Becas Doctorado en Chile) and Instituto de Investigaciones Agropecuarias INIA, project 502655-70. 
Figure 7. Olfactory preference index (OPI) values of Oligonychus yothersi to synthetic $\alpha$-pinene, $R$-limonene, farnesene (racemic mixture), linalool $\left(0.1,1,10\right.$, and $\left.100 \mu \mathrm{gL}^{-1}\right)$, ocimene (racemic mixture) and methyl salicylate $(1,10,100$ and $\left.1000 \mu \mathrm{g} \mathrm{mL}^{-1}\right)$.
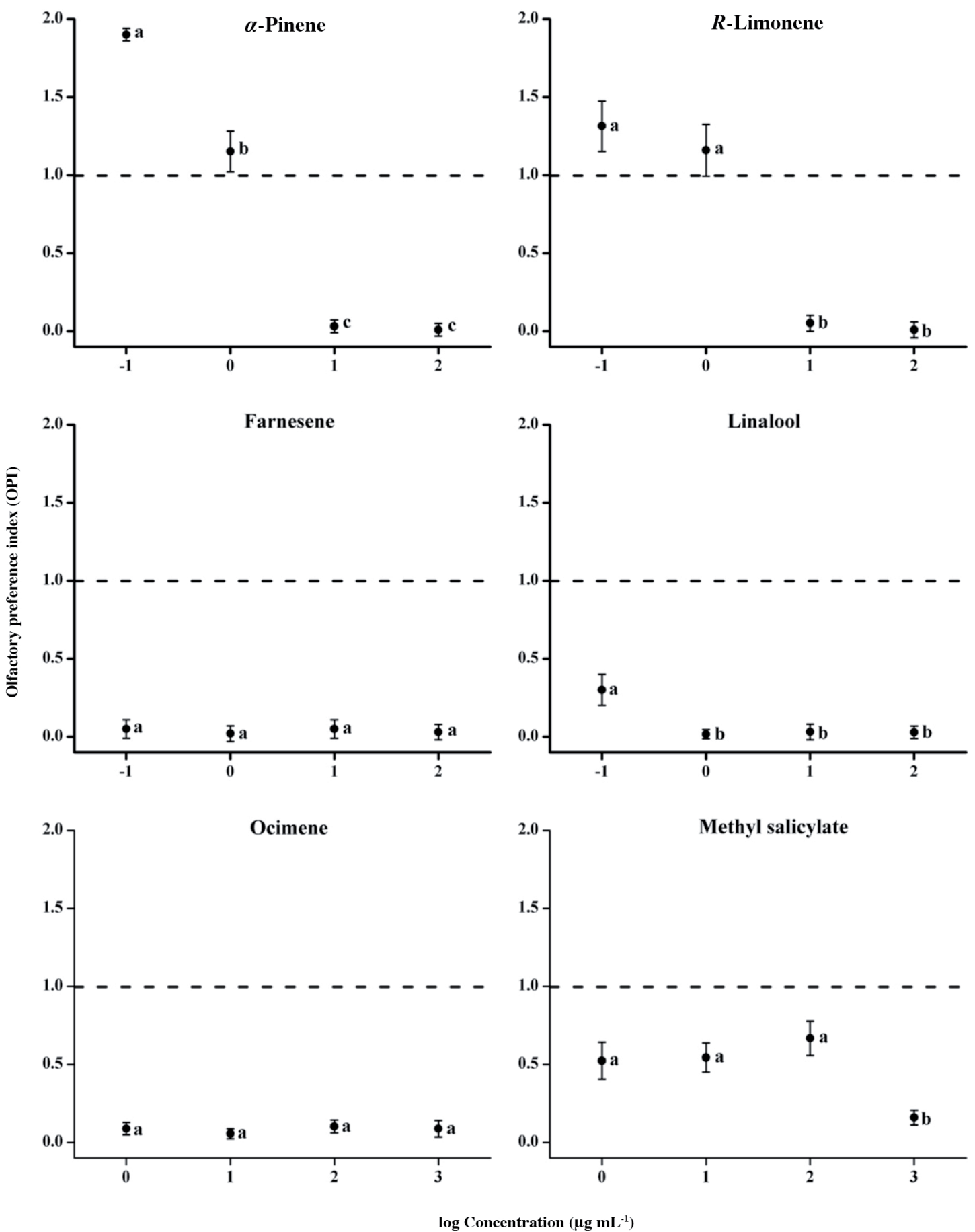

OPI values sharing a letter are non-significantly different based on Kruskal-Wallis test $(\mathrm{P}<0.05)$ followed by Mann-Whitney's U-Test $(\mathrm{P}<0.05)$ weighted by the Bonferroni correction. 


\section{REFERENCES}

Alhmedi, A., Haubruge, E., and Francis, F. 2010. Identification of limonene as a potential kairomone of the harlequin ladybird Harmonia axyridis (Coleoptera: Coccinellidae). European Journal of Entomology 107:541-548.

Biddinger, D.J., Weber, D.C., and Hull, L.A. 2009. Coccinellidae as predators of mites: Stethorini in biological control. Biological Control 51:268-283. doi:10.1016/j.biocontrol.2009.05.014.

Cao, Y.,Zhi, J., Cong, C., and Margolies, D.C. 2014. Olfactory cues used in host selection by Frankliniella occidentalis (Thysanoptera: Thripidae) in relation to host suitability. Journal of Insect Behavior 27:41-56. doi:10.1007/s 10905-013-9405-5.

Ceballos, R., Fernández, N., Zuñiga, S., and Zapata, N. 2015. Electrophysiological and behavioral responses of pea weevil Bruchus pisorum L. (Coleoptera: Bruchidae) to volatiles collected from its host Pisum sativum L. Chilean Journal of Agricultural Research 75:202-209. doi:10.4067/S0718-58392015000200009.

Choh, Y., and Takabayashi, J. 2010. Herbivore-induced plant volatiles prime two indirect defences in lima bean. p. 255-258. In Sabelis, M., and Bruin, J. (eds.) Trends in Acarology. Springer, Dordrecht, Netherlands.

de Rijk, M., Dicke, M., and Poelman, E.H. 2013. Foraging behaviour by parasitoids in multiherbivore communities. Animal Behaviour 85:1517-1528. doi:10.1016/j.anbehav.2013.03.034.

Encinas-Basurto, D., Valenzuela-Quintanar, M.I., Sanchez-Estrada, A., Tiznado-Hernandez, M.E., Rodriguez-Felix, A., and Troncoso-Rojas, R. 2017. Alterations in volatile metabolites profile of fresh tomatoes in response to Alternaria alternata (Fr.) Keissl. 1912 infection. Chilean Journal of Agricultural Research 77:194-201 . doi:10.4067/S0718-58392017000300194.

Ferrero, M., Tixier, M.S., and Kreiter, S. 2014. Different feeding behaviors in a single predatory mite species. 1. Comparative life histories of three populations of Phytoseiulus longipes (Acari: Phytoseiidae) depending on prey species and plant substrate. Experimental and Applied Acarology 62:313-324. doi:10.1007/s10493-013-9745-z.

Gadino, A.N., Walton, V.M., and Lee, J.C. 2012. Olfactory response of Typhlodromus pyri (Acari: Phytoseiidae) to synthetic methyl salicylate in laboratory bioassays. Journal of Applied Entomology 136:476-480. doi:10.1111/j.1439-0418.2011.01670.x.

Gencer, N., Kumral, N., Sivritepe, H., Seidi, M., Susurluk, H., and Senturk, B. 2009. Olfactory response of the ladybird beetle Stethorus gilvifrons to two preys and herbivore-induced plant volatiles. Phytoparasitica 37:217-224. doi:10.1007/s12600-009-0032-9.

Hoy, M. 2011. Predatory insects and plant-feeding mites. Agricultural acarology. Introduction to integrated mite management. p. 185-210. CRC Press, Boca Raton, Florida, USA.

Ishii, Y., and Shimada, M. 2012. Learning predator promotes coexistence of prey species in host-parasitoid systems. Proceedings of the National Academy of Sciences 109:5116-5120. doi:10.1073/pnas.1115133109.

Kappers, I.F., Hoogerbrugge, H., Bouwmeester, H.J., and Dicke, M. 2011. Variation in herbivory-induced volatiles among cucumber (Cucumis sativus L.) varieties has consequences for the attraction of carnivorous natural enemies. Journal of Chemical Ecology 37:150-160. doi:10.1007/s10886-011-9906-7.

Kessler, A., and Heil, M. 2011. The multiple faces of indirect defences and their agents of natural selection. Functional Ecology 25:348-357. doi:10.1111/j.1365-2435.2010.01818.x.

Köllner, T.G., Lenk, C., Schnee, C., Köpke, S., Lindemann, P., Gershenzon, J., et al. 2013. Localization of sesquiterpene formation and emission in maize leaves after herbivore damage. BMC Plant Biology 13:15. doi:10.1186/1471-2229-13-15.

Lee, J.C. 2010. Effect of methyl salicylate-based lures on beneficial and pest arthropods in strawberry. Environmental Entomology 39:653-660. doi:10.1603/EN09279.

Li, S.J., Ren, S.L., Xue, X., Ren, S.X., Cuthbertson, A.G.S., van Dam, N.M., et al. 2014. Efficiency of plant induced volatiles in attracting Encarsia formosa and Serangium japonicum, two dominant natural enemies of whitefly Bemisia tabaci in China. Pest Management Science 70:1604-1610. doi:10.1002/ps.3749.

Loreto, F., Dicke, M., Schnitzler, J.P., and Turlings, T.C.J. 2014. Plant volatiles and the environment. Plant, Cell and Environment 37:1905-1908. doi:10.1111/pce.12369.

Lucas-Barbosa, D., van Loon, J.J.A., and Dicke, M. 2011. The effects of herbivore-induced plant volatiles on interactions between plants and flower-visiting insects. Phytochemistry 72:1647-1654. doi:10.1016/j.phytochem.2011.03.013.

Maffei, M.E. 2010. Sites of synthesis, biochemistry and functional role of plant volatiles. South African Journal of Botany 76:612-631. doi:10.1016/j.sajb.2010.03.003.

Mithöfer, A., and Boland, W. 2012. Plant defense against herbivores: Chemical aspects. Annual Review of Plant Biology 63:431450. doi:10.1146/annurev-arplant-042110-103854.

NIST/NIH/EPA. 2005. NIST/NIH/EPA Mass spectral library. NIST Standard Reference Database 1A NIST 05. Standard Reference Data Program. National Institute of Standards and Technology (NIST), National Institutes of Health (NIH), Environmental Protection Agency (EPA), Gaithersburg, Maryland, USA.

Oliveira, M.S., and Pareja, M. 2014. Attraction of a ladybird to sweet pepper damaged by two aphid species simultaneously or sequentially. Arthropod-Plant Interactions 8:547-555. doi:10.1007/s11829-014-9336-x. 
Ozawa, R., Nishimura, O., Yazawa, S., Muroi, A., Takabayashi, J., and Arimura, G. 2012. Temperature-dependent, behavioural, and transcriptional variability of a tritrophic interaction consisting of bean, herbivorous mite, and predator. Molecular Ecology 21:5624-5635. doi:10.1111/mec.12052.

Perumalsamy, K., Selvasundaram, R., Roobakkumar, A., Rahman, V.J., Babu, A., and Muraleedharan, N.N. 2009a. Life table and predation of Oligota pygmaea (Coleoptera: Staphylinidae) a major predator of the red spider mite, Oligonychus coffeae (Acarina: Tetranychidae) infesting tea. Biological Control 51:96-101. doi:10.1016/j.biocontrol.2009.07.002.

Perumalsamy, K., Selvasundaram, R., Roobakkumar, A., Rahman, V.J., and Muraleedharan, N. 2009b. Life table and predatory efficiency of Stethorus gilvifrons (Coleoptera: Coccinellidae), an important predator of the red spider mite, Oligonychus coffeae (Acari: Tetranychidae), infesting tea. Experimental and Applied Acarology 50:141. doi:10.1007/s 10493-009-9290-y.

Ponzio, C., Gols, R., Pieterse, C.M.J., and Dicke, M. 2013. Ecological and phytohormonal aspects of plant volatile emission in response to single and dual infestations with herbivores and phytopathogens. Functional Ecology 27:587-598. doi:10.1111/1365-2435.12035.

Raghava, T., Ravikumar, P., Hegde, R., and Kush, A. 2010. Spatial and temporal volatile organic compound response of select tomato cultivars to herbivory and mechanical injury. Plant Science 179:520-526. doi:10.1016/j.plantsci.2010.07.020.

Rioja, T., Ceballos, R., Holuigue, L., and Vargas, R. 2016. Different population densities and continuous feeding by Oligonychus yothersi (McGregor) (Acari: Tetranychidae) affect the emissions of herbivore-induced plant volatiles on avocado (Persea americana Mill. cv. Hass) shoots under semi-field conditions. International Journal of Acarology 42:310-318. doi:10.1080/01647954.2016.1191539.

Rioja, T., Ceballos, R., Rebolledo, R., and Vargas, R. 2015. Rearing and development of Oligota pygmaea and Parastethorus histrio (Coleoptera: Staphylinidae, Coccinellidae) feeding on Oligonychus yothersi (Acari: Tetranychidae) and survival on nonmite foods under laboratory conditions. International Journal of Acarology 41:681-687. doi:10.1080/01647954.2015.1094513.

Sabelis, M.W., Janssen, A., and Takabayashi, J. 2011. Can plants evolve stable alliances with the enemies' enemies? Journal of Plant Interactions 6:71-75. doi:10.1080/17429145.2011.556262.

Shimoda, T. 2010. A key volatile infochemical that elicits a strong olfactory response of the predatory mite Neoseiulus californicus, an important natural enemy of the two-spotted spider mite Tetranychus urticae. Experimental and Applied Acarology 50:9-22. doi:10.1007/s10493-009-9275-x.

Simpson, M., Gurr, G.M., Simmons, A.T., Wratten, S.D., James, D.G., Leeson, G., et al. 2011. Insect attraction to synthetic herbivore-induced plant volatile-treated field crops. Agricultural and Forest Entomology 13:45-57. doi:10.1111/j.1461-9563.2010.00496.x.

Suckling, D.M., Twidle, A.M., Gibb, A.R., Manning, L.M., Mitchell, V.J., Sullivan, T.E.S., et al. 2012. Volatiles from apple trees infested with light brown apple moth larvae attract the parasitoid Dolichogenidia tasmanica. Journal of Agricultural and Food Chemistry 60:9562-9566. doi:10.1021/jf302874g.

Uefune, M., Choh, Y., Abe, J., Shiojiri, K., Sano, K., and Takabayashi, J. 2012. Application of synthetic herbivore-induced plant volatiles causes increased parasitism of herbivores in the field. Journal of Applied Entomology 136:561-567. doi:10.1111/j.1439-0418.2011.01687.x.

Uefune, M., Nakashima, Y., Tagashira, E., Takabayashi, J., and Takagi, M. 2010. Response of Wollastoniella rotunda (Hemiptera: Anthocoridae) to volatiles from eggplants infested with its prey Thrips palmi and Tetranychus kanzawai: Prey species and density effects. Biological Control 54:19-22. doi:10.1016/j.biocontrol.2010.02.008.

van Wijk, M., de Bruijn, P.J.A., and Sabelis, M.W. 2011. Complex odor from plants under attack: Herbivore's enemies react to the whole, not its parts. PLOS ONE 6:e21742. doi:10.1371/journal.pone.0021742.

Woods, J.L., James, D.G., Lee, J.C., and Gent, D.H. 2011. Evaluation of airborne methyl salicylate for improved conservation biological control of two-spotted spider mite and hop aphid in Oregon hop yards. Experimental and Applied Acarology 55:401. doi:10.1007/s10493-011-9495-8. 